\title{
Analysis of SCADA Application on Distribution System Reliability
}

\author{
Noveri Lysbetti Marpaung \\ Departement of Electrical \\ Engineering \\ Faculty of Engineering \\ Universitas Riau \\ Pekanbaru, Indonesia \\ noveri.marpaung@gmail.com
}

\author{
Edy Ervianto \\ Departement of Electrical \\ Engineering \\ Faculty of Engineering \\ Universitas Riau \\ Pekanbaru, Indonesia \\ edyervianto@gmail.com
}

\author{
Rahyul Amri \\ Departement of Electrical \\ Engineering \\ Faculty of Engineering \\ Universitas Riau \\ Pekanbaru, Indonesia \\ rahyulamri@yahoo.com
}

\author{
Hayatul Illahi \\ Departement of Electrical \\ Engineering \\ Faculty of Engineering \\ Universitas Riau \\ Pekanbaru, Indonesia \\ hayatulillahi42@gmail.com
}

\begin{abstract}
Reliability of Electrical Power Distribution to consumer is strongly influenced by its distribution system. Therefore, electrical power distribution system with high reliability is needed. In distribution of electrical power, reliability level of distribution system is very necessary, because it is influential strongly factor towards continuity of electrical energy distribution to consumers. Parameters can be used to determine reliability level of Electrical Power Distribution System are SAIDI, SAIFI, and CAIDI. SCADA on Electrical Power Ditribution System is needed because it can monitor, control, configure and record working system real time. Besides it, SCADA also can handle interruption temporary or permanently in short time by using remote. Aim of this research is to compare distribution system reliability index such as SAIFI, SAIDI and CAIDI before and after integrated with SCADA in Bukittinggi Rayon of PT PLN (Persero), West Sumatera, Indonesia. This research uses Distribution System Data from 2015 and 2016. Result of this research is Realibility Index before Integrated with SCADA(2015) are 15.40 hours/customer, 46.36 interruption/year, 0.33 hour/year, while after Integrated with SCADA(2016) are 2.14 hours/customer, 22.41 interruption/year, 0.10 hour/year. for SAIDI, SAIFI CAIDI Index respectivel $y$. It can be concluded that the increase of Reliability Index after integrated with SCADA are $86.1 \%$ for SAIDI, $\mathbf{5 1 . 6 6 \%}$ for SAIFI, $\mathbf{6 9 . 7 \%}$ for CAIDI.
\end{abstract}

Keywords-Distribution System, Reliability Index, SAIDI, SAIFI, CAIDI.

\section{INTRODUCTION}

Reliability of Electrical Power Distribution to consumer is strongly influenced by its distribution system. Therefore, electrical power distribution system with high reliability is needed. Reliability in distribution system is measurement of availability level from electrical supply and how often the system experiences interruptions, causes interruptions and how long to recover the interruptions occured (how fast does it take to recover the interruptions occured).

In distribution of electrical power, reliability level of distribution system is very necessary, because it is influential strongly factor towards continuity of electrical energy distribution to consumers. Therefore, calculation of reliability index is very necessary, in order to know how much reliability level of a distribution system is. Parameters can be used to determine reliability level of Electrical Power Distribution System are System Average Interruption Duration Index (SAIDI), System Average Interruption Frequency Index (SAIFI), and Costumer Average Interruption Duration Index (CAIDI).

Supervisory Control and Data Acquisition (SCADA) on Electrical Power Ditribution System is really needed because it can be used to monitor, control, configure and record working system real time. Besides it, SCADA also can handle interruption temporary or permanently in short time by using remote from Control Centre. All these abilities are the advantages when using SCADA in a Ditribution System.

By applying SCADA in Ditribution Sistem, hopefully, it can give service quality that more efficient and effective to costumers. It also can minimize financial losses as impact of system realibilty that is susceptible to intrruptions.

In addition, network maintenance and evaluation of performance system can be done regularly based on existing daily data. Both interference data and reading data from equipment system are very necessary, because they can help to improve reliability of electrical power distribution system.

Aim of this research is to compare distribution system reliability index such as SAIFI, SAIDI and CAIDI before and after integrated with SCADA in Bukittinggi Rayon of PT PLN (Persero), Western Sumatera, Indonesia. To reach the goal, so this research uses Distribution System Data in Bukittinggi Rayon of PT PLN (Persero) from 2015 and 2016.

\section{LITERATURE REVIEW}

\section{A. Distribution System Reliability}

Distribution System is part of the Electrical Power System. Electrical Power Distribution System is a distributor of electrical power from Bulk Power Source to consumers. Distribution System is a part of Electrical Power System that deals directly with consumers. Electrical voltage generated by the power station is increased at the substation through a 
step-up transformer to be greater voltage, before transmitted through the transmission line [1].

Increasing electricel voltage generated is to reduce voltage losses in transmission line. In this case, power losses is proportional to the square of current flowing $\left(\mathrm{P}=\mathrm{I}^{2} \mathrm{R}\right)$. With the same power, if the voltage value is enlarged, the current flowing be smaller. Therefore, power losses also be smaller. From transmission line, voltage is reduced tobe 20 $\mathrm{kV}$ with step down transformer on the distribution substation. Then, with this voltage system, Electrical Power Distribution is carried out by the Primary Distribution Line. From the Primary Distribution Line, the distribution substations decrease voltage to be lower voltage of $220 / 380 \mathrm{~V}$ with a Secondary Distribution Transformer. Then this voltage is distributed to consumers by Secondary Distribution Network [1].

Reliability System of Electrical Power Distribution in general is a system that works in certain circumstances that is demanded to be able to deliver electricity continuously to customers in accordance with the standards set with guaranteed safety and quality of distributed electricity. Level of Distribution System Reliability can be divided into three, namely [1]:

1. High Reliability System

2. Medium Reliability System

3. Low Reliability System

Reliability Index in a system can be measured both in terms of the substation and feeder. The level of reliability in a distribution system can be determined by calculating the System Average Interruption Frequency Index (SAIFI) and System Average Interruption Duration Index (SAIDI). SAIFI states the frequency characteristics or the number of disturbances while SAIDI states characteristics of duration (duration of measured disturbance) in a one-year period [1].

\section{System Average Interruption Duration Index}

System Average Interruption Duration Index (SAIDI) is a reliability index which is the average number of hours per year for each customers without electricity. SAIDI can be calculated using Equation 1 [2, 3, 4].

$$
S A I D I=\frac{\sum_{i}\left(N_{i} \cdot \mathrm{r}_{i}\right)}{\sum_{T} N_{T}}
$$

Whereas :

- $\mathrm{N}_{\mathrm{i}}=$ Number of customers interrupted

- $r_{i}=$ Down time (hour/year)

- $\mathrm{N}_{\mathrm{T}}=$ Served number total of customers

2. System Average Interruption Frequency Index

System Average Interruption Frequency Index (SAIFI) is a reliability index which is average number of interruptions per year that affecting each customer. SAIFI can be formulated as shown in Equation 2 [2, 3, 4].

Whereas :

$$
S A I F I=\frac{\sum_{i}\left(N_{i} \cdot \lambda_{i}\right)}{\sum_{T} N_{T}}
$$

- $\mathrm{N}_{\mathrm{i}}=$ Number of customers interrupted

- $\quad \lambda_{\mathrm{i}}=$ Failure Number of frequency in year (failure/year)

- $\mathrm{N}_{\mathrm{T}}=$ Served number total of customers

3. Costumer Average Interruption Duration Index
Costumer Average Interruption Duration Index (CAIDI) is the average number of hours per year for each customers without electricity divided by average number of interruptions per year that affecting each customer. Formulation of CAIDI can be seen in Equation 3 [2, 3, 4].

$$
C A I D I=\frac{\sum_{i}\left(N_{i} \cdot \mathrm{r}_{i}\right)}{\sum_{i}\left(N_{i} \cdot \lambda_{i}\right)}=\frac{S A I D I}{S A I F I}
$$

\section{B. SCADA System}

SCADA is a system that collect information or data from field, then send those data to central computer that will arrange and control all the data. SCADA on Electrical Power System is a system that perform monitoring, controlling and processing data from Electrical Power System in real time. SCADA components namely Master Station, Telecommunication Media, and Remote Station/Remote Terminal Unit (RTU). SCADA get real time data from RTU or others communication resources in the field, so operator (dispatcher) make possible to do supervisory of Electrical Power network operation and controlling of remote-control operation [5].

Telecommunication Media is used as data sending in SCADA from RTU to Master Station. There are many Telecommunication Media, such as Power Line Carrier (PLC), Fibre Optic Network, Radio Link/GPRS and others communication media [5]. Basic functions of SCADA are [5]:

1. Telemetering (TM): to send information about measurement results in certain time, like as voltage, current, frequency. Monitoring by dispatcher, such as displaying real Power in MW, Reactive Power in Mvar, Voltage in KV, and Current in A. Therefore, dispatcher can monitor all information needed centrally.

2. Telesignal (TS): sending signal states status of an information equipment. Information sent namely status of Disconnecting Switch (PMT), Circuit Breaker (PMS), alarm avalaibility and others signals.

3. Telecontrol (TC): Command to open or close tool of Electrical Power System can be done by dispatcher using remote.

Three most important parts from SCADA System, are [6]:

1. Master Station: Main component of SCADA in Master Station is Master Terminal Unit (MTU) like main computer or server. There are two servers that work as master (main computer) and other as slave (master eplacement if there is any interruption). Main other components in Master Station are:

a. Mimic Board: electronic board to display a controlled Electrical Power System, such as PMT in each substation connected to RTU. Status data is obtained from server that take those data by polling system or with interruption system from all RTUs.

b. Mimic Dynamic: is monitor display to show detailed and dynamic towards substation status on Medium Voltage Power.

c. Man-Machine Interface (MMI): Computer is used to connect server to computer for operator. All and detail data from each substation will be shown on computer screen. Those information is obtained from 
telemetering that can not be seen from mimic board. From MMI, operator does all Telecontrol function.

d. Logger: to record all occurrences from each substation. Logger can analyze and detect interruption sources or problems easier.

e. Communication Media is media to connect between equipments to change information about happening between Master Station with RTU. Materials can be used for are Fiber Optic, Control Radio, Modem.

2. Remote Terminal Unit (RTU) is microprossesor that do scanning, managing and storing data in temporary memory before it asked by Master Station and do controlling agree with requested from Master Station. RTU is installed on each Substation or Power Station in Electrical Power Network.

Generally, RTU is computer equipment in Remote Station or network location that can be monitored by Control Center. Funtions of RTU are :

a. To detect change of switch positions (open/close/invalid).

b. To read measurement and calculation. RTU takes and process data about current or voltage value gained from transducer that connected to it.

c. Receive Remote Control Command from Master Station to open and close.

d. RTU will do command to open and close connected Load Breaker Switch (LBS).

e. Sending data and information to Master Station consist of switch status, execution result, and values of voltage, current and frequency.

SCADA application on Electrical Power Distribution Network can render efficient in controlling time and electrical network restoration, reducing interruption area, and also increasing electrical power distribution service to consumers. SCADA can do load maneuver if interruption occured. Load behinds interruption point from substation that beginning supply towards interruption can be moved to other substations, so electrical energy supplier to load which is free interruption still can be distributed [7]. Without any occured interruption, so service quality to consumers be better electrical power supply can be done well. Consumers will not experince any losses, production keep working, productivity increase, quota can be filled, and continuity of electrical energy service be better. From economy, losses electrical energy caused interruptions can be saved electrical company will not experience financial losses [7].

\section{Literature References}

Reference [8] was Reliability Evaluation of certain substation can be achieved by reducing the failure rate of the sensitive components or subsystems in power system by raising mean time between failures. Power system reliability can be achieved by decreasing mean down-time. Reliable electric power will deduct costs and losses that are associated with insufficient and non-availability of electric power and also increase efficiency, productivity, effectiveness and the quality of power output.

Reference [9] was impact of Directional Relays (DRs) on reliability evaluation with normally closed loop distribution system by using the reliability index. In case of changing radial system to the normally closed loop system, reliability of distribution system can be increased or decreased due to affects the load linked feeder each other.
Reference [2] was reliability of electrical power is maintaining the continuity of electrical power distribution to customer, especially customers used large power who require it absolutely. However, in the last few decades, reliability of distribution network is less noticeable than reliability of generating system. Therefore it is necessary to do evalution to improve distribution system reliability based on customeroriented index, such as System Average Interruption Frequency Index (SAIFI), System Average Interruption Duration Index (SAIDI), Customer Average Interruption Duration Index (CAIDI), Average Service Availability Index (ASAI) and Average Service Unavailability Index (ASUI). In this research, only SAIFI Index will be discussed.

Reference [7] was one indicator of distribution system reliability is durability of electricity supply to consumers. Therefore, a system that can perform real-time supervising nd controlling based on computer is needed. In this case, SCADA system is chosen by taking into account several parameters of distribution network reliability index. Some of reliability indices are SAIDI, SAIFI, CAIDI.

Reference [10] was reliability is working opportunity of a system as its frame work in certain interval time and condition. To increase reliability can be done by taking actions such as, planning SCADA supporting infrastructure using fuse cut out, installing distance relay on the network and improving protection relay coordination, whereas this study are focused on Over Current Relay (OCR) and Ground Fault Relay (GFR).

Reference [11] was SCADA System Reliability with Recloser placement design to evaluate distribution system reliability based on how the failure of a component affects system operation. Effects of disturbances systematically are identified directly through SCADA system. From evaluation results obtained, SCADA system design on distribution system can increase its distribution system reliability. With a good reliability system, customer service can be improved, as well as the operational efficiency of the electrical power system, especially on distribution network to be increased.

Reference [12] was that SCADA has been known and started to be implemented in controlling of electric power systems since early 1980s. After applying a SCADA system, reliability index SAIDI and SAIFI much better because saving time increase up to $95,53 \%$ and frequency of outages 4 times less than that before implementing the SCADA System. This research different place of distribution system, and number of feeders used as a reference, while previous studies discussed only one feeder is used as a reference.

\section{Methodology}

The research was conducted in of National Electrical Company (PT. PLN Persero) Bukittinggi Rayon located on Jalan Jendral Sudirman No. 1, Bukittinggi, Padang - Western Sumatera, Indonesia from December 2016 until January 2017.

The existing data of reliability raising from Distribution System in PT. PLN (Persero) Bukittinggi Rayon, can be seen from data in 2015 and 2016. There are two types of applied variables in this study, namely:

1. Independent Variable: Disturbances of several feeders in Bukittingi City Distribution System in 2015 and 2016. 
2. Dependent Variable: interrupted duration from one feeder in Bukittinggi Distribution System in 2015 and 2016.

Flowchart of this research is shown in Fig. 1.

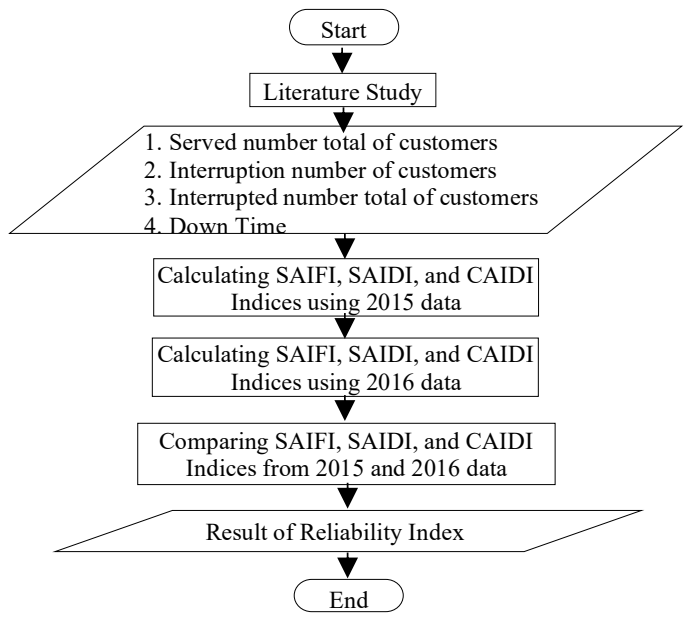

Fig. 1. Flowchart of research

\section{RESUlts AND DisCUSSION}

\section{A. Data Used in Calculations}

In general, to find out reliability level of Distribution System in Bukittinggi Rayon of PT. PLN (Persero), West Sumatera is determined by number of occured Interrupt, Duration of Interrupt, and number of customers who experience interruption in certain time. This study uses data before integrated with SCADA (2015) and after integrated with SCADA (2016) with four different feeders which are counted in Interrupted Number Total of Customers. The name of four feeders in Bukittinggi Rayon of PT. PLN (Persero), Western Sumatera, Indonesia are Palupuah, Koto Baru, belakang Balok, Kampung China.

\section{B. Calculation of Reliability Indices Before Integrated with SCADA}

Data of four feeders before integrated with SCADA in 2015 in Bukittinggi Rayon of PT. PLN (Persero) is shown in Fig. 2.

Data of Served number total of customers, Interruption number of customers, Interrupted number total of customers and Interrupted Duration before integrated with SCADA in 2015 can be seen in Fig. 3.

To calculate SAIDI value before integrated with SCADA in January 2015, Equation 1 is used:

$$
S A I D I=\frac{13587 \times 0.58}{47657}=0.17 \text { hour } / \text { customer }
$$

To calculate SAIFI value before integrated with SCADA in January 2015, Equation 2 is used:

$$
\text { SAIFI }=\frac{4 \times 13587}{47657}=1.14 \text { Times interrupted/ Month }
$$

With same way, SAIDI and SAIFI Index before integrated with SCADA for February - December in 2015 can be obtained. SAIDI and SAIFI Index before integrated with SCADA for January - December in 2015 in Bukittinggi Rayon of PT. PLN (Persero) can be seen in Fig. 4. To calculate CAIDI value before integrated with SCADA in 2015, using Equation 3:

$C A I D I=\frac{S A I D I}{\text { SAIFI }}=\frac{15.40}{46.36}=0.33$ hour $/$ year

C. Calculation of Reliability Indices After Integrated with SCADA

Data of four feeders after integrated with SCADA in 2016 in Bukittinggi Rayon of PT. PLN (Persero) is shown in Fig. 5.

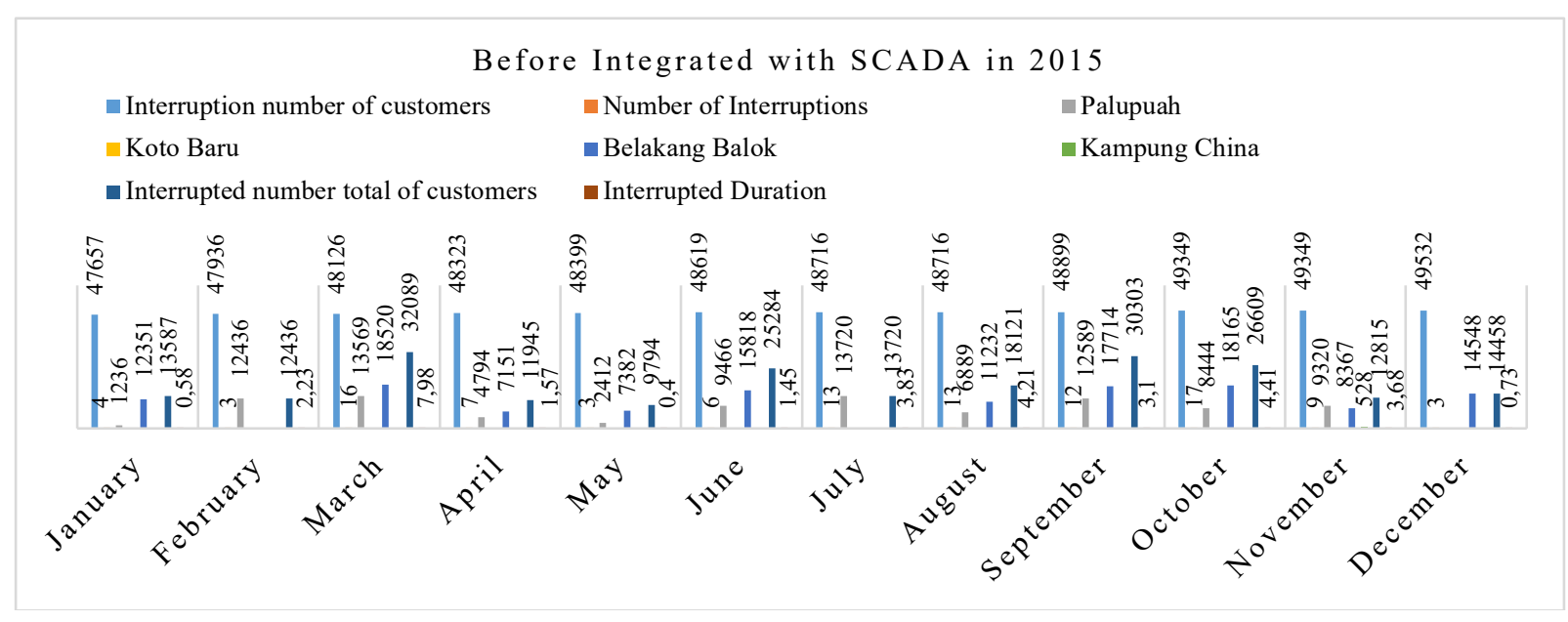

Fig. 2. Data of four feeders before integrated with SCADA in 2015 


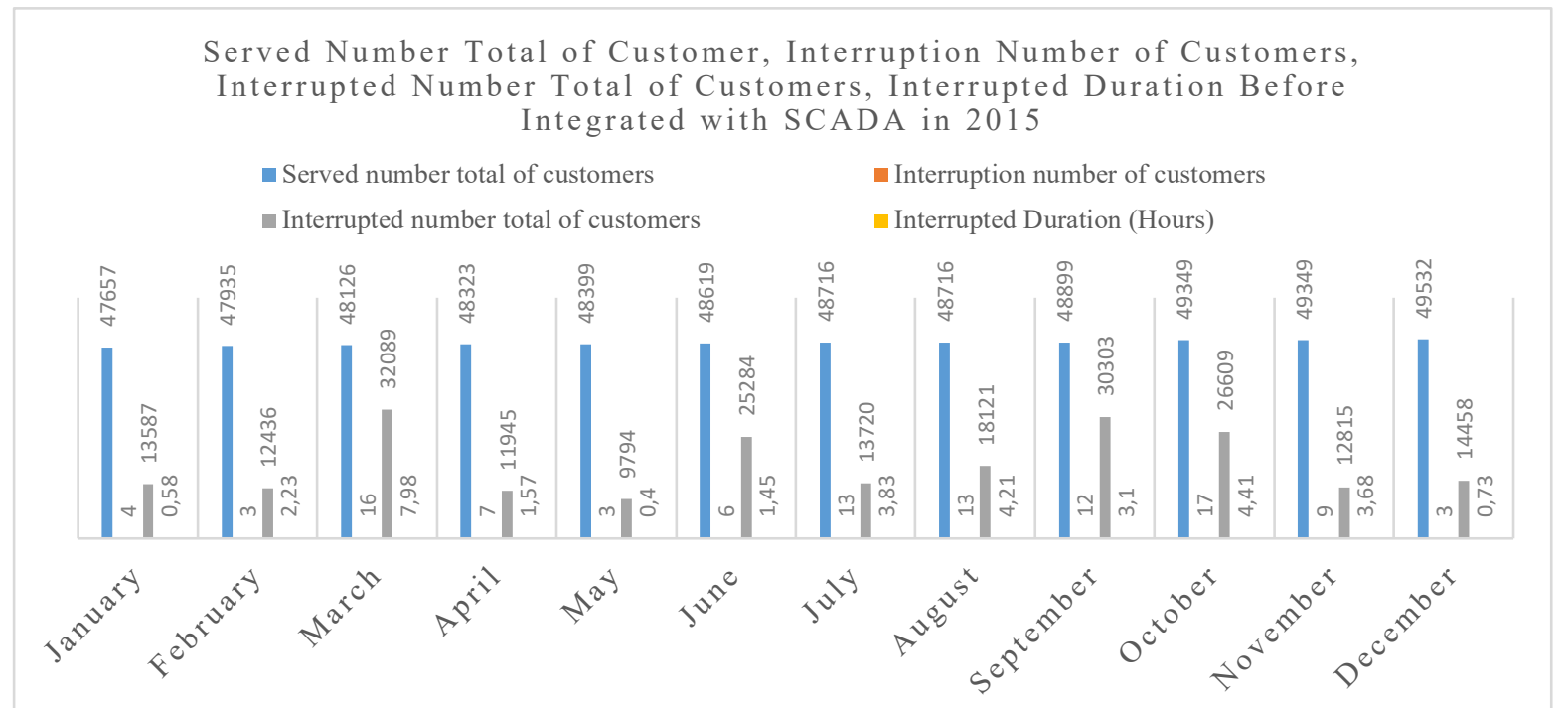

Fig. 3. Data Served number total of customers, Interruption number of customers, Interrupted number total of customers and Interrupted Duration before integrated with SCADA in 2015

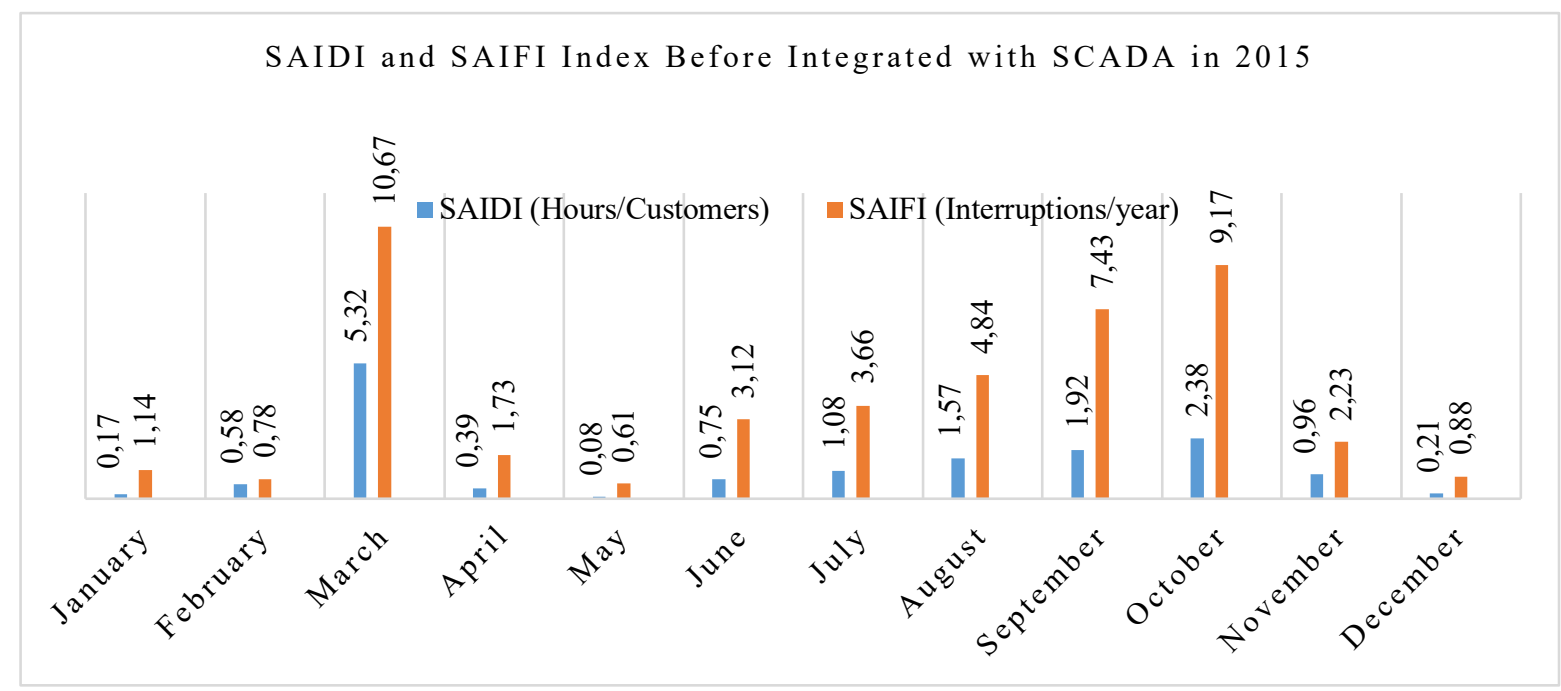

Fig. 4. SAIDI and SAIFI Index before integrated with SCADA for January - December in 2015

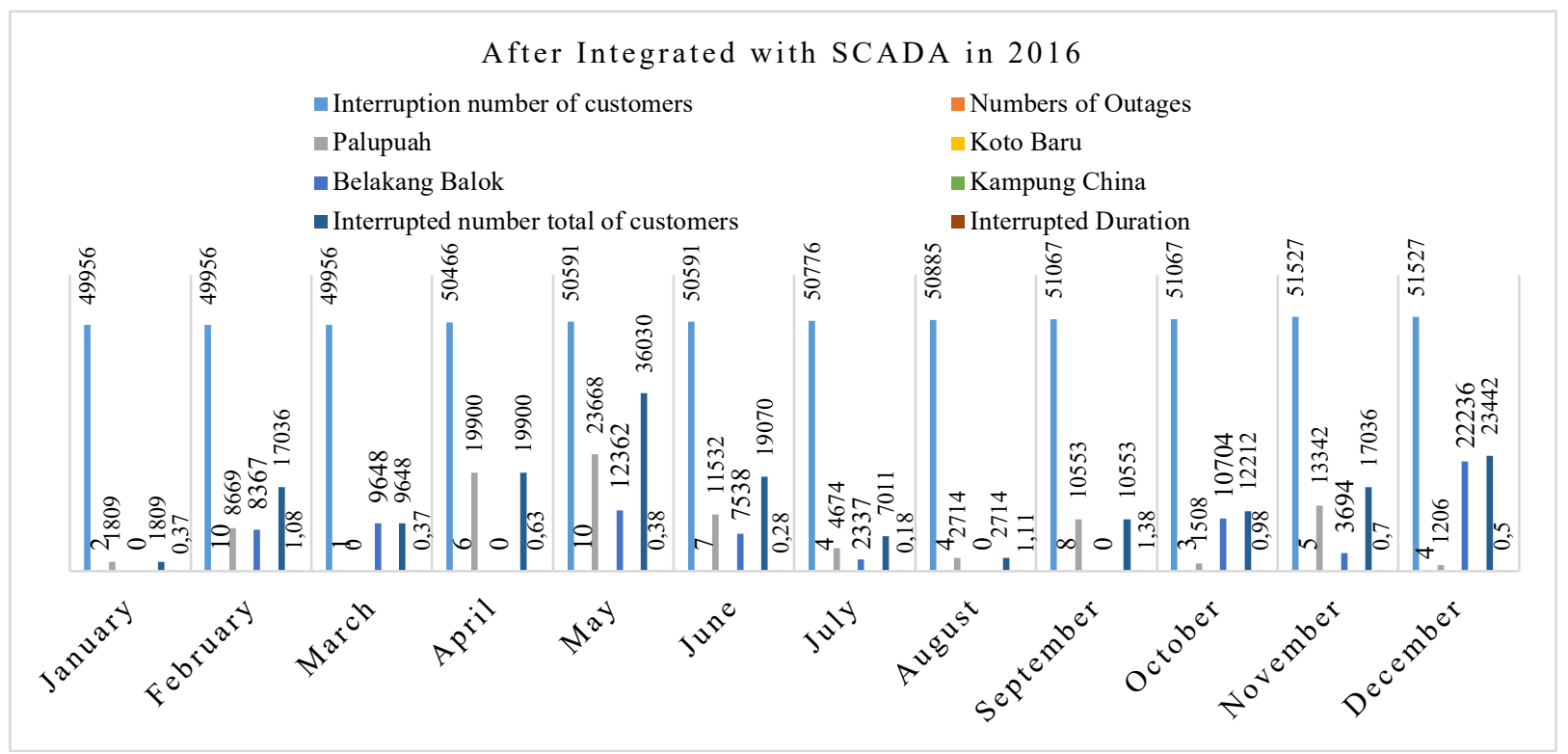

Fig. 5. Data of four feeders after integrated with SCADA in 2016 in Bukittinggi Rayon of PT. PLN (Persero) 


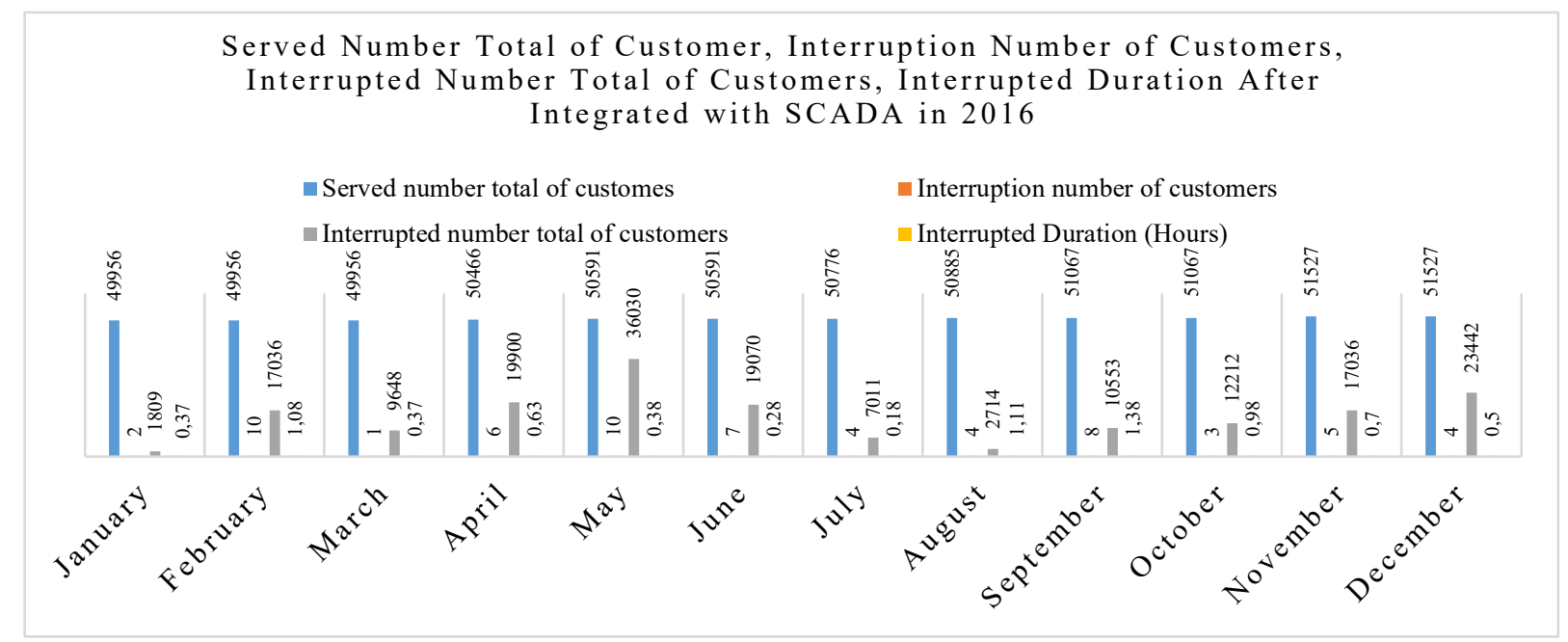

Fig. 6. Served number total of customers, Interruption number of customers, Interrupted number total of customers and Interrupted Duration after integrated with SCADA in 2016

Data of Served number total of customers, Interruption number of customers, Interrupted number total of customers and Interrupted Duration after integrated with SCADA in 2016 can be seen in Fig. 6. To calculate SAIDI value after integrated with SCADA in January 2016, Equation 1 is used:

$$
S A I D I=\frac{1809 \times 0.37}{49956}=0.01 \text { hour } / \text { customer }
$$

To calculate SAIFI value after integrated with SCADA in January 2016, Equation 2 is used:

$$
\text { SAIFI }=\frac{2 \times 1809}{49956}=0.07 \text { Times interrupted/ Month }
$$

With same way, SAIDI and SAIFI Index after integrated with SCADA for February - December in 2016 can be calculated. SAIDI and SAIFI Index after integrated with SCADA for January - December in 2016 in Bukittinggi Rayon of PT. PLN (Persero) can be seen in Fig. 7.

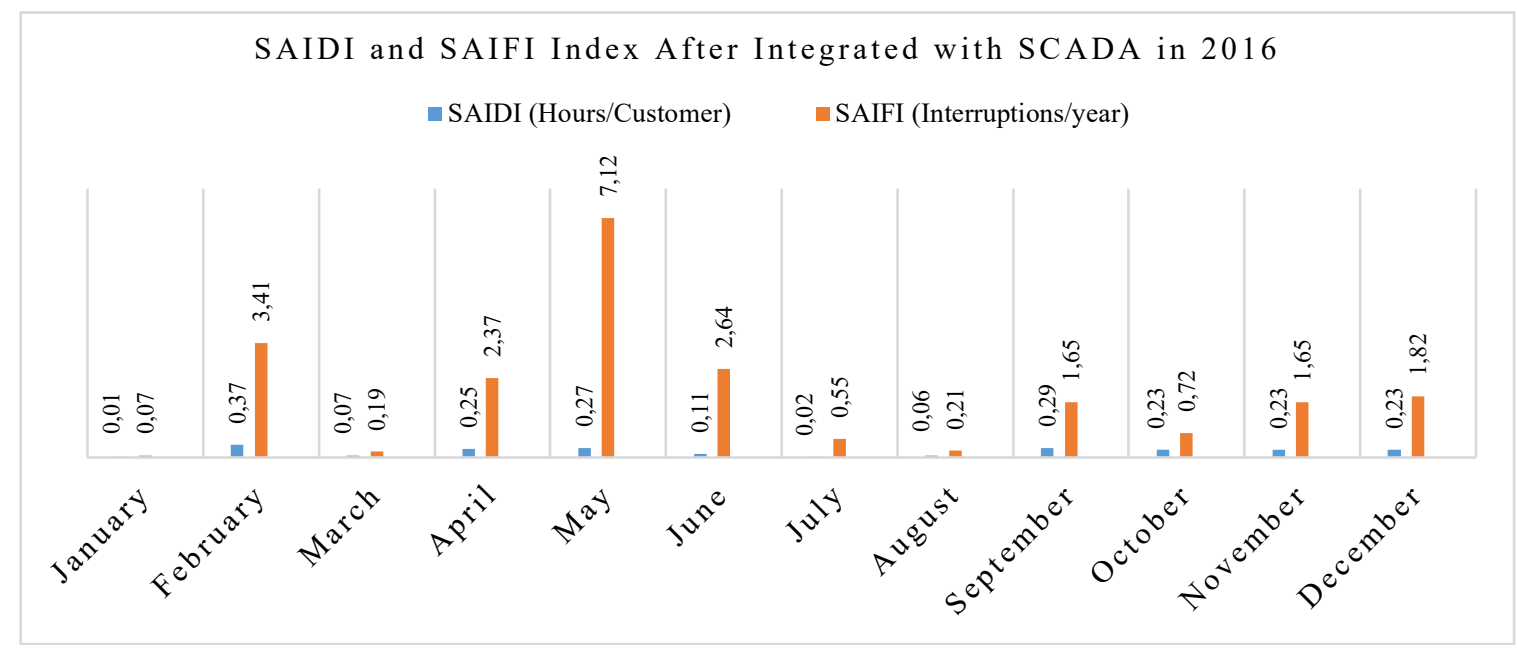

Fig. 7. SAIDI and SAIFI Index after integrated with SCADA for January - December in 2016

With same way, CAIDI value in 2016 is calculated by using Equation 3:

$$
C A I D I=\frac{S A I D I}{\text { SAIFI }}=\frac{2.14}{22.41}=0.10 \text { hour } / \text { year }
$$

Based on collected data, Reliability Index of Distribution System in Bukittinggi Rayon from PT. PLN (Persero) can be seen from comparison of reliability level of Distribution System before integrated with SCADA (2015) and after integrated with SCADA (2016) with parameters that can be used such as SAIDI, SAIFI, and CAIDI.

Based on the calculation results of SAIDI, SAIFI and CAIDI Values, so The Realibility Comparison Index in 2015 and 2016, is shown in Figure 8. Based on Figure 8, can be seen the increase of Reliability Index after integrated with SCADA. 


$$
\begin{aligned}
& \text { SAIDI Index }=\frac{\text { SAIDI } 2015-\text { SAIDI } 2016}{\text { SAIDI } 2015} \times 100 \% \\
& \text { SAIDI Index }=\frac{15.40-2.14}{15.40} \times 100 \%=86.1 \% \\
& \text { SAIFI Index }=\frac{\text { SAIFI } 2015-\text { SAIFI } 2016}{\text { SAIFI } 2015} \times 100 \% \\
& \text { SAIFI Index }=\frac{46.36-22.41}{46.36} X 100 \%=51.66 \% \\
& \text { CAIDI Index }=\frac{\text { CAIDI } 2015-\text { CAIDI } 2016}{\text { CAIDI } 2015} \times 100 \% \\
& \text { CAIDI Index }=\frac{0.33-0.10}{0.33} X 100 \%=69,7 \%
\end{aligned}
$$

The Realibility Comparison Index of SAIDI, SAIFI and CAIDI in 2015 and 2016

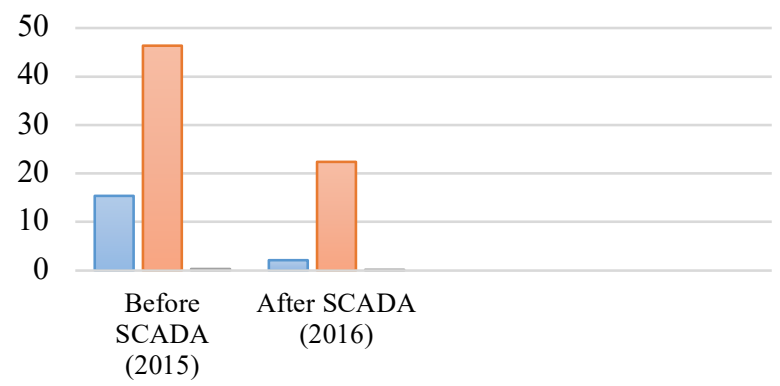

$\square$ SAIDI (Hours/Customers) $\square$ SAIFI (Interruption/Year) $\square$ CAIDI (Hour/Year)

Fig. 8. The Realibility Comparison Index of SAIDI, SAIFI and CAIDI in 2015 and 2016

The Increase of Reliability Index after integrated with SCADA in 2016, can be seen in Figure 9.

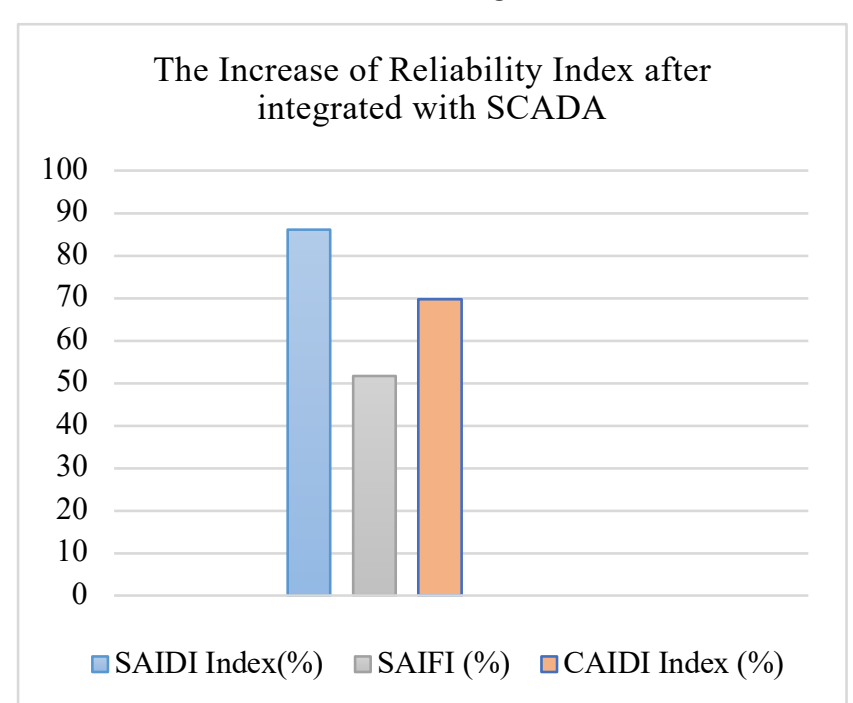

Fig. 9. The Increase of Reliability Index after integrated with SCADA in 2016

\section{CONCLUSION}

SAIDI Index in Bukittinggi Rayon of PT. PLN (Persero) after Integrated with SCADA in 2016 increased upto $86.1 \%$. SAIFI Index in Bukittinggi Rayon of PT. PLN (Persero) after Integrated with SCADA in 2016 increased upto 51.66\%. CAIDI Index in Bukittinggi Rayon of PT. PLN (Persero) after Integrated with SCADA in 2016 increased upto $69.7 \%$.

\section{REFERENCES}

[1] D. Marsudi, "Electrical Power Operating System, First Edition (Operasi Sistem Tenaga Listrik, Edisi Pertama)," Graha Ilmu Publisher, Yogyakarta, 2006.

[2] S. Saodah, "Reliability Evaluation of Electrical Power Distribution System Based on SAIDI and SAIFI (Evaluasi Keandalan Sistem Distribusi Tenaga Listrik Berdasarkan SAIDI Dan SAIFI)," 2008 Science and Technology Application National Seminar (Seminar Nasional Aplikasi Sains dan Teknologi 2008). Institut Sains dan Teknologi Akprind Publisher, Yogyakarta, pp 45-51, 2008

[3] L. Bertling, C. J. Wallnerstrom, "Exercises on Reliability Assessment of Electric Power Systems," KTH - Royal Institute of Technology, School of Electrical Engineering, Stockholm, pp 5, 2007.

[4] H. Illahi, N.L. Marpaung, "Analyze and Evaluation of Using SCADA on Distribution System Realibility of PT PLN Persero in Distribution Divisor Area of Riau and Riau Island (Analisa dan Evaluasi Penggunaan SCADA Pada Keandalan Sistem Distribusi PT. PLN Persero Area Pembagi Distribusi Riau dan Kepulauan Riau)", JOM FTEKNIK Vol 4 No 1, Universitas Riau, Pekanbaru, pp 1-8, 2017.

[5] B Pandjaitan, "Technology of Electrical Power Controlling System Based on SCADA) (Teknologi Sistem Pengendalian Tenaga Listrik Berbasis SCADA," Prenhallindo Publisher, Jakarta, 1999.

[6] R. Novel, "Design Analysis of SCADA System on Electrical System of Universitas Indonesia (Analisa Perancangan Sistem SCADA Pada Sistem Kelistrikan Universitas Indonesia)," Universitas Indonesia, Jakarta, 2009.

[7] K. Julianto, D.W. Nugraha, "Using Evaluation of SCADA in Distribution System Reliability of PT PLN (Persero) in Palu Rayon (Evaluasi Penggunaan SCADA Pada Keandalan Sistem Distribusi PT. PLN (Persero) Area Palu)," Mektrik Journal, Vol 1. Tadulako University. ISSN 2356-4792, Palu, Central Sulawesi, pp 1-10, 2014.

[8] T. Adefarati, A.K. Babarinde, A.S. Oluwole, K. Olusuyi, "Reliability Evaluation of Ayede 330/132KV Substation," International Journal of Engineering and Innovative Technology (IJEIT) Vol 4 Issue 4, India, pp 86-91, 2014.

[9] J-H. Park, S-M. Cho, H-S. Shin, J-C. Kim, "The Impact of Directional Relay on Reliability Evaluation of Closed Loop Distribution System," Journal of International Council on Electrical Engineering Vol. 2, No. 3, ISSN: (Print) 2234-8972, Taylor and Francis Group, Oxfordshire, pp. 290 296, 2012.

[10] F.V. Syukra, S. Anam, S. Mahmudsyah, "Network Reliability Increase of Primary Distribution in PT.PLN (Persero), Padang Rayon) (Peningkatan Keandaalan Jaringan Distribusi Primer Pada PT PLN (Persero) Cabang Padang," POMITS Journal Vol. 1, No 1, Jurusan Teknik Sistem Perkapalan, (Department of Shipping System Engineering), Institut Teknologi Sepuluh Nopember, Surabaya, pp 16, 2013.

[11] M. Soleh, "System Design for Service and Efficiency Increasing of Electrical Power System Operational in APJ Cirebon (Desain Sistem SCADA Untuk Peningkatan Pelayanan Dan Efisiensi Operasional Sistem Tenaga Listrik di APJ Cirebon)," IncomTech, Telekomunikasi and Komputer Journal Vol. 5, No 1, ISSN 2085-4811, Universitas Mercu Buana, Jakarta, pp 25-44, 2014.

[12] I. Pujotomo, "Implementation of SCADA System for Controlling 20 KV Distribution Network (Implementasi Sistem SCADA Untuk Pengendalian Jaringan Distribusi $20 \mathrm{KV}$ ), Kajian Teknik Elektro Journal Vol.1 No.1, Universitas 17 Agustus 1945, Jakarta, pp 51-66, 2016. 